\title{
PENJUALAN BBM ILLEGAL DI DALAM KAPAL LAUT DITINJAU DARI UNDANG- UNDANG NOMOR 20 TAHUN 2001
}

\author{
Angela Claresta Foek \\ Fakultas Hukum Universitas Surabaya \\ angelfoek8@gmail.com
}

DOI: https://doi.org/10.23917/laj.v4i2.8794

\author{
Submission \\ Track: \\ Received: \\ 9 September 2019 \\ Final Revision: \\ 4 Oktober 2019 \\ Available online: \\ 10 Oktober 2019 \\ Corresponding \\ Author: \\ Angela Claresta Foek \\ angelfoek8@gmail.com
}

\begin{abstract}
ABSTRAK
Penelitian ini dimaksudkan untuk menganalisis perbuatan yang dilakukan oleh pelaku (DB) yaitu melakukan tindakan pidana korupsi menjual bahan bakar minyak yang didapat secara illegal ditinjau dari Undang-Undang Nomor 20 Tahun 2001 Tentang Perubahan atas Undang-Undang Nomor 31 Tahun 1999 tentang Pemberantasan Tindak Pidana Korupsi. Pada kasus DB yang melakukan tindak pidana korupsi menjual bahan bakar minyak yang didapat secara illegal di dalam kapal dapat dikenakan pasal 2 jo. Pasal 18 Undang-Undang Nomor 20 Tahun 2001 Tentang Perubahan atas Undang-Undang Nomor 31 Tahun 1999 tentang Pemberantasan Tindak Pidana Korupsi jo. Pasal 64 ayat jo. Pasal 55 ayat (1) ke-1 KUHP.
\end{abstract}

Kata Kunci: penjualan bahan bakar minyak illegal, tindak pidana korupsi; Undang- Undang Nomor 20 Tahun 2001 Tentang Perubahan atas Undang-Undang Nomor 31 Tahun 1999 tentang Pemberantasan Tindak Pidana Korupsi.

This study was intended to analyze the actions committed by the prepetrator $(D B)$ who commited criminal acts of corruption by selling illegally obtained fuel oil in view of the Law Number 20 of 2001 on Amendments to Law Number 31 of 1999 on Eradication of Crime of Corruption Crime. In the case of $D B$ who commited a criminal act of corruption by selling fuel oil which was illegally obtained from the ship could be subjected to Article 2 jo. Article 18 Law Number 20 of 2001 on Amendments to Law Number 31 of 1999 on Eradication of Corruption Crimes jo. Article 64 paragraph jo. Article 55 paragraph (1) number 1 of the Criminal Code.

Keywords: Sale of Illegal Fuel Oil, Crime of Corruption; Law Number 20 of 2001 on Amendment to Law Number 31 of 1999 on Eradication of Corruption Crime. 


\section{PENDAHULUAN}

Bahan bakar minyak atau yang biasa dikenal dengan istilah BBM telah menjadi salah satu kebutuhan primer manusia dewasa ini. Hampir setiap hari segenap lapisan masyarakat menggunakan BBM untuk menunjang aktivitas transportasi mereka. Perkembangan dunia yang semakin modern, semakin meningkatkan konsumsi masyarakat terhadap BBM,dan berpotensi meningkatkan harganya dari waktu ke waktu.

Hal tersebut menimbulkan peluang bagi pihak-pihak tertentu untuk memanfaatkan situasi tersebut dengan cara menjual BBM secara illegal. Dalam arti melakukan penjualan BBM tanpa izin sebagaimana diatur di dalam ketentuan peraturan perundang-undangan yang secara khusus mengatur hal tersebut yaitu, Peraturan Pemerintah Nomor 36 Tahun 2004 tentang Kegiatan Usaha Hilir Minyak dan Gas Bumi. Kegiatan usaha minyak dan gas bumi terdiri atas kegiatan usaha hulu dan kegiatan usaha hilir.

Usaha penjualan bahan bakar minyak termasuk ke dalam kegiatan usaha hilir yaitu niaga. Niaga adalah kegiatan pembelian, penjualan, ekspor, impor minyak bumi dan/atau hasil olahannya, termasuk niaga gas bumi melalui pipa. Merujuk pada pasal 2 Peraturan Pemerintah Nomor 36 Tahun 2004 tentang Kegiatan Usaha Hilir Minyak dan Gas Bumi, kegiatan usaha hilir dilaksanakan oleh badan usaha yang telah memiliki izin usaha yang dikeluarkan oleh Menteri dan diselenggarakan melalui mekanisme persaingan usaha yang wajar, sehat, dan transparan. Pasal 5 angka 2 Undang-Undang Nomor 22 Tahun 2001 tentang Minyak dan Gas Bumi menentukan bahwa kegiatan usaha hilir yang mencakup pengelolaan, pengangkutan, penyimpanan, dan niaga. Diperjelas dengan adanya Pasal 23 ayat (1) Undang-Undang Nomor 22 Tahun 2001 tentang Minyak dan Gas Bumi disebutkan kegiatan usaha hilir sebagaimana dimaksud dalam Pasal 5 angka 2 Undang-Undang Nomor 22 Tahun 2001 tentang Minyak dan Gas Bumi, dapat dilaksanakan oleh Badan Usaha setelah mendapatkan Izin Usaha dari Pemerintah.Sehingga dalam melaksanakan kegiatan usaha pembelian, penyimpanan, dan penjualan BBM harus berbentuk badan usaha, bukan perorangan.

Republik Indonesia adalah negara hukum. Hal tersebut diatur dalam konstitusi negara Indonesia yang tertuang dalam Pasal 1 ayat (3) Undang-undang Dasar Negara Kesatuan Republik Indonesia. Ketentuan tersebut merupakan landasan konstitusional bahwa hukum ditempatkan sebagai salah satu norma utama yang mengatur kehidupan bermasyarakat, berbangsa dan bernegara di Indonesia. Penjualan BBM yang tidak sesuai dengan peraturan perundang-udangan adalah hal yang illegal, dan bahkan dapat dikategorikan sebagai tindak pidana korupsi.

Kasus yang diangkat di dalam artikel ini adalah Kasus DB bermula pada tahun 2004 dimana DB menjabat sebagai mualim 1 kapal MT Santana milik PT Pelumin. DB bertugas mengangkut bahan bakar minyak berupa solar dan premium milik PT Pertamina (Persero) sebanyak 1.600 kilo liter dari unit pengeolaan II Dumai menuju Terminal BBM Pekanbaru Sei Siak. DB mengangkut solar dan premium dari unit pengelolaan II Dumai ke Terminal BBM Pekanbaru Sei Siak enam hingga delapan kali dalam satu bulan. Setiap memindahkan BBM ternyata tangki BBM tidak bisa terserap habis, selalu menyisakan tiga hingga lima kilo liter. Akan tetapi master, surveyor, dan pihak kapal mengeluarkan Dry 
Certificate.

DB menjual sisa BBM milik PT Pertamina (Persero) saat hendak kembali ke unit pengelolaan II Dumai. Sisa BBM yang tidak bisa terserap dipindahkan ke dalam tangki nomor 3. DB kemudian menghubungi DN untuk memindahkan BBM tersebut dari kapal Santana ke kapal Tanker Lautan 1 atau Kapal Tanker Lautan 3 milik AM dengan cara ship to ship di tengah perairan wilayah Dumai.

DB memeriksa dan memastikan bahwa sisa minyak BBM milik PT Pertamina (Persero) di tanki nomor 3 telah habis dipindahkan ke kapal tanker lautan 1 atau kapal tanker lautan 3. Penjualan tersebut dilakukan sekitar tiga hingga lima kali dalam satu bulan. Jumlah BBM sisa yang dijual sekitar lima belas hingga dua puluh kilo liter. Penjualan BBM sisa PT Pertamina (Persero) tersebut DN melakukan pembayaran kepada WY dengan mentransfer uang ke rekening mandiri DB dengan total Rp 6.079.300.000,00. DB mendapat delapan hingga sembilan persen atau sekitar Rp 486.344.000,00 hingga Rp 547.137.000,00, kemudian uang tersebut juga dibagikan kepada empat belas kru kapal, empat pegawai PT Pertamina (Persero) dan dua petugas surveyor.

Pada tahun 2011 tepatnya pada tanggal 12 Januari 2011 DB berhenti bekerja dari kapal MT Santana milik PT Pelumin. Pada 21 Juli 2013 DB bekerja di SPOB Melisa milik PT Agni Putra Jasa Kusuma. Selaku Mualim 1 dengan tugas dan tanggungjawab menghitung muatan, merencanakan stabilitas kapal, dan mempersiapkan tanki muatan.

Kapal SPOB Melisa adalah jenis Motor Tanker dengan kapasitas 2.600 kilo liter dan kapal tersebut mengangkut premium dan solar milik PT Pertamina (Persero). Dengan rute Dumai atau Sei Pakning menuju ke terminnal BBM Sei Siak di Pekanbaru. Adapun jumlah perjalanan dalam pemuatan BBM setiap bulannya dari Dumai menuju Pekanbaru sekitar empat kali muat setiap bulannya. DB juga mengetahui benar bahwa BBM berupa premium dan solar yang diangkut oleh kapal SPOB Melisa adalah milik PT Pertamina (Persero).

Setiap kali kapal SPOB Melisa melakukan proses bongkar muatan DB mengetahui masih terdapat sisa BBM dalam tangki kapal SPOB Melisa. Seperti pada sebelumnya yang terjadi pada kapal tangki milik PT Santana dimana sisa BBM yang tidak dapat terisap oleh pompa kapal. Pihak loading master, surveyor, dan pihak kapal tetap menerbitkan "Dry Certificate" padahal sudah diketahui oleh DB secara benar bahwa terdapat klausul "Transportation Losses" pada perjanjian kontrak sewa kapal. Bahwa terhadap sisa BBM setelah dilakukan proses bongkar adalah merupakan milik negara dan milik PT Pertamina (Persero) yang seharusnya diserahkan kembali oleh kapal SPOB Melisa, Akibat dari perbuatan tersebut telah merugikan keuangan negaracasu quo PT Pertamina (Persero)sebesar Rp 149.760.938.624,00.

DB didakwa dengan Dakwaan Primair:

Pasal 2 ayat (1) jo. Pasal 18 Undang-Undang R.I. No. 31 tahun 1999 sebagaimana telah diubah dan ditambah dengan Undang-Undang No. 20 Tahun 2001 tentang Pemberantasan Tindak Pidana Korupsi Jo. Pasal 64 ayat (1) KUHP jo. Pasal 55 ayat (1) ke-1 KUHP.

Dakwaan Subsidair: 
Pasal 3 jo Pasal 18 Undang-Undang R.I. No. 31 tahun 1999 sebagaimana telah diubah dan ditambah dengan Undang-Undang No. 20 Tahun 2001 tentang Pemberantasan Tindak Pidana Korupsi jo Pasal 64 ayat (1) jo Pasal 55 ayat (1) ke-1 KUHP.

Putusan Pengadilan Negeri Pekanbaru menyatakan DB tidak terbukti secara sah dan meyakinkan bersalah melakukan tindak pidana yang sebagaimana di dakwakan primair maupun subsidair, serta membebaskan terdakwa dari semua dakwaan tersebut, hakim juga menyatakan bahwa pengadilan tindak pidana korupsi tidak berwenang mengadili perkara tindak pidana pencucian uang oleh terdakwa DB.

\section{METODE PENELITIAN}

Artikel ini menggunakan metode penelitian hukum yuridis normatif, yaitu penelitian hukum yang dilakukan terhadap bahan hukum primer yang terdiri dari peraturan perundangundangan atau literatur- literatur lainnya, serta penelitian terhadap asas-asas hukum dan terhadap sistematika hukum yang berkaitan untuk menjawab permasalahan dalam penelitian ini.

Pendekatan masalah yang digunakan dalam penelitian ini adalah statute approach dan conceptual approach. Pendekatan statute approach adalah pendekatan yang dilakukan dengan menelaah semua undang-undang dari regulasi yang bersangkut paut dengn isu hukum yang sedang dihadapi. (Marzuki, 2014, hal.133) Pendekatan conceptual approach adalah pendekatan yang beranjak dari pandangan-pandangan dan doktrin-doktrin yang berkembang di dalam ilmu hukum (Marzuki, 2014, hal. 135).

\section{HASIL DAN PEMBAHASAN}

Perkara tindak pidana korupsi sebelum ditetapkan sebagai perkara yang merugikan negara, maka harus melalui perhitungan. Perhitungan kerugian keuangan negara bukan hanya pendekatan pencatatan, tambah kurang menggunakan kalkulator, atau alat perhitungan lainnya, karena didalamnya terdapat terminologi "kerugian ada terdapat unsur perbuatan melanggar hukum yang mengakibatkan terjadi rugi”. (R. Bayu Ferdian, Mohd.Din, M. Gaussyah, 2018, hal. 330). Kerugian akibat korupsi secara signifikan mengurangi kapasitas negara dalam membangun perekonomian dan menyediakan fasilitas kesejahteraan sosial. (Deddy Chandra, Arifin, 2018, hal. 29). Dalam konteks hukum pidana, korupsi merupakan tindak pidana yang sulit dibuktikan. (Puteri Hikmawati, 2018, hal. 28).

Analisis kasus dilakukan terhadap pertanggungjawaban pidana disertai perbarengan tindak pidana yang ada dan penyertaan para pelaku. Pertanggungjawaban pidana sesuai asas tiada pidana tanpa kesalahan menurut pendapat Moeljatno (1987, hal. 167), yakni:

Dalam hal pertanggungjawaban pidana dalam hukum pidana, menganut asas tiada pidana tanpa kesalahan (geen straf zonder schuld), walaupun tidak dirumuskan dalam undangundang, tetapi dianut dalam praktik. Tidak dapat dipisahkan antara kesalahan dan pertanggungjawaban atas perbuatan. Orang yang melakukan dengan kesalahan saja yang dapat dibebani dengan tanggung jawab atas tindak pidana yang dilakukannya. 
Untuk menjelaskan kesalahan, maka diuraikan unsur-unsur sesuai pendapat Moeljatno yakni:

Untuk adanya kesalahan terdakwa harus:

a. Melakukan perbuatan pidana (sifat melawan hukum)

Unsur melakukan perbuatan pidana yang melawan hukum. Moeljatno (2011, hal. 30) berpendapat bahwa: "perbuatan pidana adalah perbuatan yang dilarang oleh suatu aturan hukum, yang disertai ancaman atau sanksi yang berupa pidana tertentu, bagi barangsiapa yang melanggar larangan tersebut."

b. Di atas umur tertentu mampu bertanggungjawab.

Pasal 44 dan Pasal 45 KUHP dijelaskan bahwa seseorang/pelaku dapat dicela dan mampu bertanggungjawab ditentukan oleh beberapa faktor yang dalam hal ini Moeljatno (2011, hal. 66) berpendapat berupa:

1. Faktor akal/batin, jiwa beserta fungsinya dalam keadaan normal, yaitu dapat membeda-bedakan antara perbuatan yang diperbolehkan dan yang tidak diperbolehkan.

2. Faktor kehendak yang berkaitan dengan perbuatan pidana, yaitu dapat menyesuaikan tingkah lakunya dengan keinsyafan atas mana diperbolehkan dan mana yang tidak.

Unsur mampu bertanggungjawab dalam tindak pidana meliputi:

Menginsyafi makna dari perbuatannya;
-
Menginsyafi perbuatan tersebut tidak patut dalam pergaulan
-
Mampu menentukan niat atau kehendaknya dalam

c. Mempunyai suatu bentuk kesalahan yang berupa kesengajaan atau kealpaan Dipidananya atau tidaknya suatu kejahatan, maka mutlak diisyaratkan adanya

"sengaja atau dolus" atau "kelalaian atau culpa" yang merupakan keharusan untuk dapat menyimpulkan adanya kesalahan. Kesalahan ini menjadi unsur penting dalam menerapkan pertanggungjawaban pidananya.

Sengaja atau dolus merupakan tindakan yang timbul dari dalam diri seseorang dikarenakan adanya dorongan niat yang besar dari dalam diri orang tersebut. Pengertian sengaja Menurut Moeljatno (2011, hal. 68) ada dua aliran yaitu:

1. Terori kehendak, dimana kesengajaan adalah kehendak yang diarahkan pada terwujudnya perbuatan seperti dirumuskan dengan undang-undang. 
2. Teori pengetahuan, mempunyai gambaran tentang apa yang ada dalam kenyataan.

Tiga jenis atau macam kesengajaan, yaitu sengaja sebagai maksud (untuk menimbulkan akibat tertentu atau dilarang), sengaja sebagai keharusan atau kepastian terjadi untuk tercapainya kejadian yang dimaksud, sengaja bersyarat (dengan mengetahui dan menghendaki menerima resiko yang besar) atau yang dikenal dengan nama sengaja sebagai kemungkinan atau dolus eventualis.

Lalai atau culpa sebagai salah satu bentuk kesalahan. Dimana cupla, memiliki pengertian kurang mengindahkan larangan, sehingga tidak berhati-hati dalam melakukan suatu perbuatan yang menimbulkan keadaan yang dilarang. Tiga komponen kealpaan yang tersembunyi meliputi:

a. Sifat melawan hukum (Unlawfullness);

b. Kelalaian (Negligence);

c. Sifat tercela (Blamewortheness).

d. Tidak adanya alasan pemaaf.

DB dapat dikenakan pertanggungjawaban pidana karena terdapat kesalahan. Unsurunsur kesalahan tersebut:

a. DB telah melakukan perbuatan melawan hukum dengan cara melakukan penjualan BBM illegal dengan perbuatan berlanjut dan sebagai pembuat (dader) suatu perbuatan pidana dikenakan

b. DB adalah orang dewasa dengan keadaan sehat dan normal sehingga mampu untuk bertanggungjawab.

c. Memenuhi bentuk kesalahan yaitu keengajaan pada saat DB secara sengaja menerima uang dan membagikan uang hasil penjualan BBM illegal.

d. Terhadap DB tidak terdapat alasan pemaaf.

Dapat dilihat unsur Pasal 2 ayat (1) Undang-Undang Nomor 31 Tahun 1999 adalah:

a. Setiap orang;

Setiap orang dalam Pasal 1 butir 3 Undang-Undang Nomor 31 Tahun 1999 tentang Pemberantasan Tindak Pidana Korupsi adalah orang perseorangan atau termasuk korporasi. Unsur pada pasal ini merupakan subyek atau pelaku tindak pidana yang dapat dimintai pertanggungjawaban atas perbuatannya. DB yang merupakan subjek atau pelaku tindak pidana yang dapat dimintai pertanggungjawaban atas perbuatannya. 
b. Secara melawan hukum;

Menurut Adami (2016, hal. 40) Dari penjelasan singkat mengenai sifat melawan hukum tersebut diatas, dapat dikatakan unsur "melawan hukum" yang dicantumkan dalam rumusan tindak pidana korupsi "memperkaya diri" Dalam pasal 2 ayat (1) UUTPK

Dimana DB secara melawan hukum dengan melakukan tindak pidana penjualan sisa BBm milik PT Pertamina (Persero) secara illegal

c. Melakukan perbuatan memperkaya diri sendiri atau suatu korporasi; Memperkaya diri sendiri artinya diri si pembuat sendirilah yang memperoleh atau bertambah kekayaannya secara tidak sah. Sedangkan memeperkaya orang lain adalah sebaliknya, orang yang kekayaannya bertambah atau memeperoleh kekayaanya adalah orang lain selain si pembuat

DB melakukan penjualan sisa BBM secara illegal dan mendapat keuntungan $8 \%$ hingga $9 \%$ untuk setiap transaksi illegal tersebut

d. Yang dapat merugikan keuangan negara atau perekonomian negara.

Dalam ketentuan ini kata "dapat" sebelum frasa "merugikan keuangan negara atau perekonomian negara" menunjukan bahwa tindak pidana korupsi merupakan delik formil, yaitu "adanya tindak pidana korupsi, cukup dengan dipenuhinya unsurunsur perbuatan yang dirumuskan, bukan dengan timbulnya akibat

Perbuatan DB menjual solar dan premium illegal mengakibatkan kerugian negara sebesar Rp 149.760.938.624,00. (seratus empat puluh sembilan miliar tujuh ratus enam puluh juta sembilan ratus tiga puluh delapan ribu enam ratus dua puluh empat rupiah)

\section{SIMPULAN}

Berdasarkan uraian dan pembahasan sebagaimana yang telah dipaparkan pada babbab sebelumnya maka dapat disimpulkan bahwa DB telah melakukan perbuatan tindak pidana korupsi yang dapat dikenakan pertanggungjawaban pidana sebagai berikut:

(1) Pasal 2 jo. Pasal 18 Undang-Undang Nomor 31 Tahun 1999 sebagaimana telah diubah dan ditambah dengan Undang-Undang Nomor 20 Tahun 2001 tentang Pemberantasan Tindak Pidana Korupsi Juncto Pasal 64 ayat (1) KUHP juncto Pasal 55 ayat (1) ke-1 KUHP.

(2) DB dapat dikenakan pertanggungjawaban pidana karena terdapat kesalahan.

Unsur-unsur kesalahan tersebut:

a. DB telah melakukan perbuatan melawan hukum dengan cara melakukan 
penjualanBBM illegal dengan perbuatan berlanjut dan sebagai pembuat (dader) suatu perbuatan pidana dikenakan

b. DB adalah orang dewasa dengan keadaan sehat dan normal sehingga mampu untuk bertanggungjawab.

c. Memenuhi bentuk kesalahan yaitu keengajaan pada saat DB secara sengaja menerima uang dan membagikan uang hasil penjualan BBM illegal.

d. Terhadap DB tidak terdapat alasan pemaaf.

Berdasarkan simpulan sebagaimana diuraikan di atas, maka seyogyanya hakim dalam memutus perkara lebih teliti dalam mengklasifikasikan tindakan pidana tersebut masuk kedalam ranah tindak pidana korupsi dengan lebih melihat unsur-unsur yang terkandung dalam pasal yang di dakwakan.

\section{REFERENSI}

Chazawi, A. (2016), Hukum Pidana Korupsi di Indonesia. Malang: Rajawali Pers.

Deddy Chandra, Arifin. 2018. Kendala Pengembalian Aset Hasil Tindak Pidana Korupsi Transnasional. Vol. 11 Nomor 2. Tahun 2018

Marzuki, P. M. (2014), Penelitian Hukum, Edisi Revisi. Jakarta: Prenada Media Group.

Moeljatno (1987), Asaz-Asaz Hukum Pidana. Bina Aksara: Jakarta.

Moeljatno (2011), Hukum Pidana Indonesia. Bandung: Refika Aditama.

Puteri Hikmawati. 2018. Operasi Tangkap Tangan Dalam Penanganan Kasus Korupsi. Pusat Penelitian Keahlian DPR RI. 30 Juni 2018.

R. Bayu Ferdian, Mohd. Din, M. Gaussyah. 2018. Penetapan Kerugian Dalam Perkara Tindak Pidana Korupsi. Vol.2(3). Desember 2018. 